\title{
DIREITOS DOS CONSUMIDORES E DEVERES DE PROTEÇÃO
}

\author{
EDUARDO ROCHA DIAS ${ }^{1}$
}

\begin{abstract}
RESUMO: Examinam-se neste artigo a disciplina traçada pela Constituição de 1988 acerca dos direitos dos consumidores e os limites de intervenção do Judiciário na determinação de medidas de proteção em situações de insuficiência dos meios disponíveis ou de inexistência de previsão por parte do legislador.

PALAVRAS-CHAVE: Direitos Fundamentais; Direitos dos Consumidor; Deveres de Proteção; Proibição de Insuficiência.
\end{abstract}

ABSTRACT: This article aims to examine the 1988 Brazilian Constitution's provisions regarding consumer rights and tries to determine limits to judiciary intervention whenever no protective measure is approved by Congress in a statute or the available measures are insufficient to enable consumer protection.

KEYWORDS: Fundamental Rights; Consumer Rights; State Protection Duties; Prohibition of Insufficient Protection Principle.

\begin{abstract}
SUMÁRIO: Introdução; 1. A dimensão objetiva dos direitos fundamentais e os deveres de proteção; 1.1. Deveres de proteção; 1.2. Direitos fundamentais e direito privado: algumas considerações; 2 . A tutela constitucional do consumidor; 3. Existência ou não de um direito subjetivo a uma medida de proteção e o princípio da proibição de insuficiência; Conclusões; Bibliografia.

SUMMARY: Introduction; 1 . The objective dimension of fundamental rights and the State's protection duties; 1.1. State's protection duties; 2.2. Some considerations regarding fundamental rights and private law; 3 - Constitutional protection of consumers; 4 . Entitlement to protective measures and the prohibition of insufficient protection principle; Conclusions; Bibliography.
\end{abstract}

\section{INTRODUÇÃO}

Pretende-se examinar neste estudo a tutela jurídica dos consumidores, a partir das previsões traçadas pela Constituição de 1988 em seus artigos $5^{\circ}$, inciso XXXII, e 170, inciso V. Em especial, almeja-se verificar se a linguagem mais objetiva, adotada em referidos dispositivos, e a remissão efetuada ao

Artigo recebido em 19.03.2011. Pareceres emitidos em 26.04.2011 e 30.04.2011.

Artigo aceito para publicação em 31.05.2011.

${ }_{1}^{1}$ Procurador Federal. Doutor pela Faculdade de Direito da Universidade de Lisboa. Professor do Programa de Pós-Graduação em Direito da Universidade de Fortaleza, Ceará. eduardordias@hotmail.com 
legislador, no tocante à disciplina da matéria, possibilita extrair diretamente da Carta Magna posições jurídicas passíveis de reconhecimento jurisdicional.

Destaque-se que a tutela jurídica dos consumidores não se insere dentre os "direitos clássicos", assim entendidos os de liberdade, de participação política e mesmo os sociais. Concretizam, na verdade, uma ampliação destes últimos, em decorrência da inserção da pessoa em relações econômicas de massa $^{2}$. Por isso mesmo se mostra necessário delimitar o âmbito de proteção que decorre de seu reconhecimento, notadamente no plano constitucional.

A proteção que resulta do reconhecimento dos direitos fundamentais, relembre-se, como posições jurídicas que estabelecem situações de vantagem em favor dos indivíduos, oponíveis precipuamente contra o Estado e, em certa medida, contra particulares, abrange dimensões múltiplas e variadas.

Fala-se, a propósito, de "gerações" de direitos fundamentais ${ }^{3}$, no sentido de que as referidas posições jurídicas, na sua afirmação histórica, se vão agregando, de maneira a construírem um sistema de tutela da pessoa em suas diversas dimensões ${ }^{4}$. Menciona-se, inicialmente, uma primeira geração de direitos fundamentais, relacionada com a pessoa individualmente considerada (direitos de liberdade), a exigirem abstenções por parte do Estado, pela qual se busca controlar o arbítrio do poder; alude-se, também, a direitos de segunda geração, a proteger a pessoa inserida socialmente, nos quais se localizam os direitos de conteúdo prestacional, a buscarem afastar a pessoa da necessidade econômica; fala-se também de direitos de terceira geração ou dimensão, a denotarem a progressiva universalização da tutela jurídica em virtude da crescente interdependência entre os povos, já que não têm como sujeitos os indivíduos, mas sim o próprio gênero humano, como os direitos ao meio ambiente, à paz e ao desenvolvimento; afirma-se, por fim, a existência de direitos de quarta e mesmo de quinta gerações ${ }^{5}$.

\footnotetext{
${ }^{2}$ Destaque-se que será priorizado neste texto o estudo do consumidor pessoa física, e não do consumidor pessoa jurídica, que também se insere na previsão traçada pelo inciso XXXII do art. $5^{\circ}$ da Carta Magna.

${ }^{3}$ Considerando a ampliação do debate acerca dos direitos um sinal premonitório do progresso moral da humanidade, examinar BOBBIO, Norberto. A Era dos Direitos. Rio de Janeiro: Campus, 1992, p. 52 e seguintes, especialmente 62-64. Fala Bobbio em uma evolução que agrega novos direitos, e que passa por processos de positivação, generalização, internacionalização e especificação (afirmação de âmbitos particulares de vigência). O mesmo autor reconhece, porém, que "uma coisa é falar dos direitos do homem, direitos sempre novos e cada vez mais extensos, e justificá-los com argumentos convincentes; outra coisa é garantir-lhe uma proteção efetiva". E arremata: "à medida que as pretensões aumentam, a satisfação delas torna-se mais difícil".

${ }^{4}$ Falando em "panjusfundamentalização", e alertando para o risco de se banalizar o discurso e a prática referente aos direitos fundamentais, pela confusão entre os que devem e os que não devem ser assim considerados, reduzindo sua eficácia, examinar NABAIS, José Casalta. Algumas Reflexões Críticas sobre os Direitos Fundamentais, in Revista de Direito Público da Economia, Ano 6, n. 22, abril/junho de 2008, Editora Fórum: Belo Horizonte, p. 74 e seguintes. Conferir, também, OTERO, Paulo. A Democracia Totalitária. Cascais: Principia, 2001, p. 153 e seguintes. ${ }^{5}$ As classificações das gerações de direitos são variadas. Examinar BONAVIDES, Paulo. Curso de Direito Constitucional. São Paulo: Malheiros, 2000, p. 514 e seguintes; GUERRA FILHO, Willis Santiago. Processo Constitucional e Direitos Fundamentais. São Paulo: RCS Editora, 2007,
} 
Há riscos, destaque-se, nessa progressiva afirmação de "gerações" de direitos. Em primeiro lugar, esclareça-se que não se trata de uma superação de "antigos" direitos por "novos" direitos: uns e outros passam a conviver, redefinindo-se e reconfigurando-se, alterando seu âmbito de proteção. Assim, por exemplo, o direito de propriedade e a liberdade contratual passam a conviver com o cumprimento de funções sociais que passa a ser associado a referidos institutos. Mas não é contra esse risco que se pretende alertar. O principal perigo é que uma afirmação inflacionária de direitos fundamentais venha a conduzir ao esgotamento financeiro do Estado, pela impossibilidade de os proteger a todos ${ }^{6}$, e à afirmação de dimensões não relevantes para a tutela da pessoa ${ }^{7}$, banalizando e enfraquecendo o discurso referente aos direitos fundamentais e assoberbando as instâncias públicas competentes para tratar do assunto, levando a uma inadequada proteção dos direitos fundamentais que efetivamente assim devem ser qualificados. A delimitação adequada do âmbito de proteção dos direitos fundamentais e das suas possibilidades de tutela jurisdicional mostra-se, portanto, indispensável.

E para tal desiderato é necessária a consideração de que os direitos fundamentais, de uma perspectiva dogmática, afirmam-se como possuidores de um duplo caráter: ${ }^{8}$

a) são direitos subjetivos; e

b) são elementos fundamentais da ordem objetiva da coletividade.

A partir dessa perspectiva, os direitos fundamentais determinam e asseguram a situação jurídica dos particulares, seu status jurídico constitucional, que não é ilimitadamente disponível nem para o particular nem para o Estado.

São os direitos fundamentais, em primeiro lugar, direitos de defesa contra o Estado, protegendo a liberdade individual e a dignidade da pessoa perante $o$ poder político. Também cumprem uma função de prestação social, assegurando ao indivíduo obter algo por meio do Estado. Exercem, em terceiro lugar, uma função de proteção do indivíduo perante terceiros, estabelecendo deveres

p. 42-43, e NABAIS, José Casalta. Algumas Reflexões Críticas sobre os Direitos Fundamentais, in Revista de Direito Público da Economia, Ano 6, n. 22, abril/junho de 2008, Editora Fórum: Belo Horizonte, p. 74 e seguintes.

${ }^{6}$ Pense-se, nesse sentido, numa defesa exacerbada da gratuidade do ensino superior público, mesmo em se tratando de pessoas que possuam nível elevado de renda, sob o argumento de não se poder privatizar o referido serviço, não se aceitando o estabelecimento de mecanismos compensatórios pelos quais os mais ricos contribuiriam para o custeio da educação superior pública, ainda que parcialmente.

$"$ É de se mencionar o caso dos defensores dos "direitos" dos animais, entendidos aqui como autênticos direitos subjetivos, e não como um dever objetivo ou uma proibição de práticas cruéis e de sofrimento desnecessário. Destaque-se, ainda, a defesa de uma incidência indiscriminada dos direitos fundamentais na ordem jurídica privada, problema que será referido brevemente no item 2.2 deste estudo.

${ }^{8}$ HESSE, Konrad. Elementos de direito constitucional da República Federal da Alemanha. Porto Alegre: Sérgio Antonio Fabris Editor, 1998, p. 228 e seg.; HÄBERLE, Peter. Le libertà fondamentali nello Stato costituzionale. Roma: La Nuova Italia Scientifica, 1993, p. 115 e seg. 
para o Estado. Os direitos fundamentais, por fim, obrigam o Estado a tratar igualmente os cidadãos, proibindo discriminações negativas. ${ }^{9}$

Nesse quadro mais geral é que se pretende situar os direitos dos consumidores, ressaltando sua jusfundamentalidade e, ao mesmo tempo, suas dimensões subjetiva e, principalmente, objetiva, no sentido de estabelecer deveres de proteção que devem ser cumpridos pelos poderes públicos. Pretende-se, ainda, examinar os limites para uma subjetivação de tais deveres de proteção e para a intervenção do Poder Judiciário no sentido de impor a adoção de uma determinada medida de tutela.

\section{A DIMENSÃO OBJETIVA DOS DIREITOS FUNDAMENTAIS E OS DEVERES DE PROTEÇÃO}

O sistema de direitos fundamentais compreende aspectos individuais e comunitários, muitas vezes imbricados. Assim, ao lado do reconhecimento e da proteção de posições jurídicas subjetivas, destinadas a tutelar bens jurídicos e interesses individuais em primeira linha, existem aspectos ligados a valores e fins que a comunidade reputa importantes, que transcendem e complementam o âmbito dos direitos individuais. O reconhecimento de tal dimensão objetiva, apontada por alguns como uma das inovações mais produtivas da teoria dos direitos fundamentais após a Segunda Grande Guerra, ao lado do princípio da proporcionalidade, ${ }^{10}$ chama a atenção para a circunstância de o sistema de direitos fundamentais não compreender apenas aspectos subjetivos. A proteção decorrente dos direitos fundamentais, com efeito, alcança também dimensões objetivas, as quais se manifestam nos direitos sociais, por exemplo, e também em uma "reinterpretação social" dos tradicionais direitos de liberdade. ${ }^{11}$

Tradicionalmente, a dimensão objetiva dos direitos fundamentais é identificada com: a) as garantias institucionais; ${ }^{12}$ b) a necessidade de edição de normas e medidas concretas relacionadas com aspectos organizativos e procedimentais; e c) a chamada eficácia externa ou horizontal dos direitos fundamentais, e atualmente com o reconhecimento de deveres de proteção contra terceiros. ${ }^{13}$ Cumpre examinar estes últimos.

\footnotetext{
${ }^{9}$ Sobre as funções dos direitos fundamentais, ver CANOTILHO, J. J. Gomes. Direito constitucional e teoria da Constituição. Coimbra: Almedina, 2003, p. 407 e seguintes.

${ }^{10}$ NOVAIS, Jorge Reis. As restrições aos direitos fundamentais não expressamente autorizadas pela Constituição. Coimbra: Coimbra Editora, 2003, p. 66.

${ }^{11}$ NOVAIS, Jorge Reis. As restrições aos direitos fundamentais não expressamente autorizadas pela Constituição, p. 65.

${ }_{12}$ ANDRADE, José Carlos Vieira de. Os direitos fundamentais na Constituição portuguesa de 1976, Coimbra: Livraria Almedina, 2004, p. 115-116; BONAVIDES. Curso de direito constitucional. São Paulo: Malheiros, 2000, p. 489-491.

${ }^{13}$ PINTO, Paulo Mota. O direito ao livre desenvolvimento da personalidade. In: AAVV. Portugal-Brasil Ano 2000: tema direito, Coimbra: Coimbra Editora, 1999, p. 187 e seg. Examinar, ainda, a obra de Claus-Wilhelm Canaris (Direitos fundamentais e direito privado, tradução de Ingo Wolfgang Sarlet. Coimbra: Livraria Almedina, 2003, p. 28 e seg.). Ingo Wolfang Sarlet menciona autonomamente a eficácia de irradiação dos direitos fundamentais, da qual decorreriam a sua eficácia na ordem
} 


\subsection{Deveres de proteção}

A eficácia "irradiante" ou "externa" dos direitos fundamentais, ${ }^{14}$ corolário de sua força vinculante, é uma de suas dimensões objetivas. A observância dos direitos fundamentais ultrapassa o plano das relações entre o Estado e os particulares, no qual estes os podem invocar com o intuito de defesa de sua esfera jurídica, mas alcança inclusive as relações entre privados, embora nem sempre sejam aplicáveis em primeira linha. ${ }^{15}$ Fala-se mais recentemente em "deveres de proteção" ou "imperativos de tutela" impostos e dirigidos ao Estado, no sentido de promover e proteger os direitos fundamentais perante terceiros, seja por meio da edição de normas, seja mediante uma atuação administrativa e fática ${ }^{16}$ É estabelecida uma relação não bipolar entre Estado e particular, mas sim triangular, na qual o Poder

jurídico-privada, as garantias institucionais, os deveres de proteção e os aspectos organizatório e procedimental, como manifestações de tal dimensão objetiva ( $A$ eficácia dos direitos fundamentais, Porto Alegre: Livraria do Advogado, 2003, p. 152 e seg.). A afirmação de uma dimensão objetiva dos direitos fundamentais, a fundar uma ordem de valores que pode eventualmente colidir com outros bens jurídico-constitucionais e com direitos titularizados pelos indivíduos, é apontada também como "porta de entrada" da metodologia da ponderação, destinada a resolver conflitos entre referidos bens e direitos. Como bem lembra José María Rodríguez de Santiago (La ponderación de bienes e interesses en el derecho administrativo, Madri: Marcial Pons, 2000, p. 24), porém, a ponderação é apenas um dos meios pelos quais de podem resolver conflitos entre bens e direitos. ${ }^{14}$ A chamada "eficácia de irradiação", expressão decorrente da decisão proferida pelo Tribunal Constitucional Federal alemão no célebre caso Lüth (Sentença $n^{\circ} 7,198$, de 15 de janeiro de 1958, da Sala Primeira) e adotada para explicar a incidência dos direitos fundamentais nas relações jurídicas privadas, tem sido criticada pela doutrina e foi inclusive abandonada pela jurisprudência posterior de referida corte. Funda-se ela no entendimento de que os direitos fundamentais, além de serem direitos de defesa contra o Estado, incluem também uma ordem de valores objetiva. Tal ordem, porém, somente se desenvolveria no direito privado, influenciando-o, por meio das disposições que predominam diretamente nesse campo do direito; ou seja, de forma mediata. Na verdade, porém, ao defender o argumento de que os juízes, ao decidirem um litígio no campo do direito privado, não se vinculam de forma direta aos direitos fundamentais, referida decisão não levou em conta o fato de que os direitos fundamentais vinculam diretamente todos os poderes estatais, inclusive o legislador de direito privado. O próprio Judiciário também se encontra vinculado, pouco importando se decide um caso de direito privado ou público. Para uma crítica da decisão Lüth e um exame de referida problemática, examinar Claus-Wilhelm Canaris (Direitos fundamentais e direito privado, p. 43 e seg.). Há tradução da decisão Lüth para o espanhol na compilação Cincuenta años de jurisprudencia del Tribunal Constitucional Federal Alemán, organizada por Jürgen Schwabe (Montevidéu; Bonn; Bogotá: Ediciones Jurídicas Gustavo Ibáñez/Konrad Adenauer Stiftung, 2003).

${ }^{15} \mathrm{Na}$ verdade, somente em situações excepcionais os direitos fundamentais serão aplicáveis diretamente nas relações jurídicas privadas, em especial quando houver expressa previsão constitucional a respeito ou quando o nível de proteção assegurado pelo direito ordinário for flagrantemente insuficiente e lesivo ao que seria exigível a fim de se proteger a dignidade da pessoa. Nesse sentido, examinar Claus-Wilhelm Canaris (Direitos fundamentais e direito privado. Tradução de Ingo Wolfgang Sarlet. Coimbra: Livraria Almedina, 2003, p. 53-55).

${ }^{16}$ Robert Alexy (Teoría de los derechos fundamentales. Madri: Centro de Estudios Políticos y Constitucionales, 2001, p. 435 e seg) trata inicialmente dos "direitos de proteção", como contrapartida subjetiva de tais deveres, invocáveis para a proteção de bens jurídicos (vida, saúde, liberdade, dignidade e outros). Tais direitos de proteção são oponíveis contra o Estado e têm por objeto a realização de ações fáticas ou normativas que delimitem a esfera jurídica de sujeitos de igual hierarquia.

DiREITOS FundaMeNTAIS E E JUSTIÇA - ANO 5, N 15, P. 79-105, ABR./Jun. 2011 
Público se coloca entre particulares com o intuito de proteger direitos fundamentais de um frente ao outro. ${ }^{17}$ Por outras palavras, em vez de um problema unidimensional de liberdade, a opor o Estado a um indivíduo, está-se diante de um problema pluridimensional de liberdade, em que o Estado, principalmente o legislador, tem a incumbência de compatibilizar bens jurídicos constitucionalmente equiparados detidos por dois ou mais particulares. É o caso das relações de consumo, em que há, de um lado, a liberdade de iniciativa e de expressão publicitária do produtor de bens e serviços, e, de outro lado, os direitos dos consumidores.

A referência a problemas uni e pluridimensionais de liberdade é tomada de empréstimo de Gunnar Schuppert, citado por Alexy. ${ }^{18}$ Para o mencionado autor, nos problemas unidimensionais de liberdade estaria presente um conflito entre interesses da comunidade e interesses individuais, para o qual haveria uma solução encontrada na interpretação já decidida pelo texto constitucional. Já nos problemas pluridimensionais de liberdade, estar-se-ia diante de uma colisão entre posições jurídicas de indivíduos ou grupos, em relação à qual não seria possível encontrar uma solução com fundamento na interpretação da Lei Fundamental. Alexy critica acertadamente tal perspectiva. Com efeito, não se trata de uma distinção muito precisa, já que nos problemas unidimensionais pode estar presente um conflito que envolva posições de indivíduos diversos, enquanto nos problemas pluridimensionais pode ocorrer uma colisão com bens da comunidade. Também não parece acertado entender que nos primeiros haveria uma solução já tendencialmente definida pela Constituição. Dado o caráter aberto da interpretação constitucional e a natural conflituosidade entre posições jurídicas decorrentes de normas de direitos fundamentais e bens comunitários, não se pode, aprioristicamente, pretender que se possa sempre obter uma resolução para qualquer modalidade dos problemas apontados que dispense ponderações. Pode-se, no máximo, considerar que a necessidade de ponderação, ou a freqüência com que ela ocorre, é maior nos problemas pluridimensionais, presentes quando está em causa a afirmação de um dever de proteção. Daí porque neste estudo se adota a distinção referida apenas para fins heurísticos.

No tocante à justiciabilidade dos deveres de proteção, portanto, não há qualquer problema que não esteja também presente no exame dos direitos fundamentais enquanto direitos de defesa. Quando se afirma, porém, a existência de um dever de proteção, impõe-se reconhecer a existência de um campo maior aberto ao legislador para a realização de prognoses e de referências ao futuro. Tal diferença quanto à amplitude dos juízos de

\footnotetext{
${ }^{17}$ CANARIS. Direitos fundamentais e direito privado. Tradução de Ingo Wolfgang Sarlet. Coimbra: Livraria Almedina, 2003, p. 58; CANOTILHO. Direito constitucional e teoria da constituição. Coimbra: Almedina, 2003, p. 409; PINTO, Paulo Mota. O direito ao livre desenvolvimento da personalidade. In: AAVV. Portugal-Brasil Ano 2000: tema direito, p. 195-196.

${ }^{18}$ Teoría de los derechos fundamentales. Madri: Centro de Estudios Políticos y Constitucionales, p. 450 e seg.
} 
prognose do legislador nos deveres de proteção, se comparada com a presente nos direitos de defesa, no entanto, é apenas gradual. Em ambos os tipos de problemas, o campo de atuação do legislador e a margem de competência do Judiciário, notadamente os tribunais constitucionais, não podem ser fixados de antemão. Ou seja, nem o legislador é livre, nem o Judiciário pode substituir ilimitadamente o legislador, nem se pode formular uma regra simples que delimite em termos definitivos a competência do primeiro e a margem de controle do Judiciário. ${ }^{19}$

É necessário não confundir, porém, os deveres de proteção impostos ao Estado (e os correspondentes direitos à proteção dos cidadãos, se e quando existirem) com a chamada eficácia dos direitos fundamentais entre particulares. Trata-se de conseqüências da dimensão objetiva de referidas posições jurídicas. Tal dimensão objetiva fundamenta ainda a vinculação positiva do legislador aos direitos fundamentais. E, na Alemanha, coube à decisão Lüth, do Tribunal Constitucional Federal, fornecer os principais argumentos dogmáticos para embasar referidas conseqüências. ${ }^{20}$

Em comum, a eficácia dos direitos fundamentais perante os particulares e os deveres de proteção impostos ao Estado têm o objetivo de proteger direitos fundamentais de um cidadão frente a outro, o que leva o Poder Público a tutelar os indivíduos contra lesões ou ameaças de lesões oriundas de outros indivíduos. Há diferenças, porém. Na vinculação dos particulares a direitos fundamentais há sempre uma relação entre particulares; nos deveres de proteção, nem sempre, podendo ocorrer no âmbito de relações entre particulares e Estados estrangeiros ou organizações internacionais. Ademais, o Estado é o destinatário dos direitos de proteção, ao passo que na vinculação entre particulares são os próprios cidadãos que revestem referida condição. A afirmação dos direitos fundamentais como direitos a proteção mostra-se compatível com a visão liberal dos direitos fundamentais. Já a afirmação de uma eficácia dos direitos fundamentais entre particulares não pode ser deduzida de tal perspectiva liberal, ou nela ser fundamentada. Os problemas envolvidos na vinculação dos particulares a direitos fundamentais podem ser tratados a partir de sua consideração como hipóteses de colisão

\footnotetext{
19 ALEXY. Teoría de los derechos fundamentales. Madri: Centro de Estudios Políticos y Constitucionales, p. 453-454.

${ }^{20}$ No caso, houve um boicote, liderado por Erich Lüth, Presidente do Clube de Imprensa de Hamburgo, contra uma película cinematográfica sob o fundamento de seu diretor haver, durante o Terceiro Reich, dirigido filmes anti-semitas e veiculado o ideário nacional-socialista. Os tribunais cíveis consideraram a exortação dirigida por Lüth um ato ilícito, por ser ofensivo aos bons costumes, condenando-o a se abster de fazê-lo. Em resposta a recurso constitucional interposto por Lüth, o Tribunal Constitucional Federal alemão cassou a decisão do tribunal cível, por entender que ela violou a liberdade de opinião e de expressão do recorrente. Sobre o tema, examinar Claus-Wilhelm Canaris (A influência dos direitos fundamentais sobre o direito privado na Alemanha. In: SARLET, Ingo Wolfgang (Org.). Constituição, direitos fundamentais e direito privado, Porto Alegre: Livraria do Advogado, 2003, p. 227-228), Karl Larenz (Metodologia da ciência do direito, Lisboa: Fundação Calouste Gulbenkian, 1989, p. 494-495) e Wilson Steinmetz (A vinculação dos particulares a direitos fundamentais, São Paulo: Malheiros, 2004, p. 105 e seg.).
} 
entre direitos fundamentais (por exemplo, entre a autonomia individual e a dignidade da pessoa). Já quando há a afirmação de um dever de proteção, nem sempre caberá falar em conflito, por inexistir uma posição jusfundamental protegida, como ocorre quando se discute o direito de um indivíduo a uma atuação policial específica (prevenção contra assaltos, por exemplo). Finalmente, a disputa sobre a eficácia direta ou indireta dos direitos fundamentais entre particulares não se coloca quando se examinam os deveres de proteção, já que nestes é o Estado que se encontra vinculado, de forma direta, a proteger direitos fundamentais de um particular diante de outro. ${ }^{21}$

Ao Estado, como destinatário de direitos de proteção e titular de deveres de tutela, cabe adotar medidas normativas e fáticas as mais variadas, como editar normas de direito penal e de direito processual penal, de direito civil e de direito processual civil, de direito administrativo, efetuar ações de polícia, que incluem medidas jurídicas e materiais, oferecer prestações jurisdicionais e outras. As medidas fáticas e normativas de proteção do consumidor se inserem nessa perspectiva. O fundamento de tais deveres de proteção parece ser o princípio do Estado de Direito. ${ }^{22}$ Com efeito, se neste último somente o Poder Público detém o monopólio da força, os indivíduos não podem, salvo nas hipóteses expressamente admitidas, como é o caso da legítima defesa, fazerem valer suas próprias razões frente a outros indivíduos. Não pode o Estado, portanto, quedar-se inerte e omitir-se ante a violação de direitos fundamentais de particulares por outros particulares. ${ }^{23}$

Tal qual ocorre no tocante à função de defesa contra o Estado, no reconhecimento de deveres de proteção, há de ser demonstrada a violação do âmbito protegido por uma norma de direito fundamental. A eficácia da função de imperativo de tutela dos direitos fundamentais, associada à proibição de insuficiência das medidas adotadas, é, porém, mais fraca do que a da função de proibição de intervenção, à qual se acopla a vedação de excesso. Isso, em primeiro lugar, pela necessidade de se argumentar a favor da existência de um dever de agir, que há de ser demonstrado, a fim de se reconhecer que o Estado não pode se omitir em determinados contextos quanto à proteção de um cidadão frente aos outros. Tal necessidade decorre da prevalência, no relacionamento entre os cidadãos, da sua autonomia individual. A dignidade da pessoa, de que tal autonomia é expressão, exige que se demonstre a existência de boas razões para uma intervenção estatal em tal campo. Em segundo lugar, tem-se que a tutela dos direitos fundamentais é operacionalizada precipuamente por meio da legislação ordinária e esta

\footnotetext{
21 Sobre essas distinções, examinar STEINMETZ. A vinculação dos particulares a direitos fundamentais. São Paulo: Malheiros, 2004, p. 131-132.

${ }^{22}$ A propósito, examinar Wilson Steinmetz ( $A$ vinculação dos particulares a direitos fundamentais. São Paulo: Malheiros, 2004, p. 129-130), que adota referido entendimento de empréstimo a Ingo von Münch. Referida fundamentação parece compatível com o ordenamento jurídico brasileiro (artigo $1^{\circ}$ da CF/88) e com o português (artigo $2^{\circ}$ da CRP).

${ }^{23}$ NOVAIS, Jorge Reis. As restrições aos direitos fundamentais não expressamente autorizadas pela Constituição. Coimbra: Coimbra Editora, 2003, p. 88.
} 
não se encontra predeterminada constitucionalmente, já que assiste ao legislador uma ampla margem de conformação. Logo, o ônus argumentativo é mais exigente para se reconhecer um défice de proteção do que para se identificar um excesso de intervenção.

A tutela de um direito fundamental pode dar-se de formas diferentes, havendo a necessidade de demonstrar que nenhuma delas é suficiente, ao passo que a ingerência em um direito torna necessário, normalmente, justificar uma única medida estatal. Tal diferença repercute inclusive sobre a amplitude do controle jurisdicional. No caso de uma medida estatal excessivamente gravosa, há uma "aptidão natural" para referido controle, pelo qual se determina, em regra, uma omissão ao Estado. ${ }^{24}$ Quando se está diante de um dever de proteção, porém, passível de ser concretizado de maneiras diferentes, há a necessidade de o Judiciário também realizar ponderações e juízos de prognose. Daí porque se deve responder separadamente a duas indagações: inicialmente, se decorre de um direito fundamental um dever de proteção imposto ao Estado; em seguida, como se deve configurar tal proteção, o que poderá levar ao reconhecimento da insuficiência das medidas adotadas. ${ }^{25}$

A necessidade de proteção de um bem jurídico pode decorrer sobretudo de atuações ilícitas de terceiros. Tal ilicitude permite aproximar a atuação de um particular lesiva de um direito fundamental do uso da força física, o que por si só seria suficiente para justificar a necessidade de proteção. ${ }^{26}$ Quando não houver tal ilicitude, porém, há de se argumentar com maior rigor. Assim, no tocante a atuações de terceiros que coloquem em risco mesmo bens primários da coletividade, como a vida e a saúde, não basta a mera identificação de uma fonte de perigo. É necessário que haja uma ameaça relevante a tais bens jurídicos, que justifique uma intervenção estatal. A ordem jurídica, globalmente considerada, deve, em conseqüência, oferecer um conjunto de instrumentos que permita uma proteção eficiente contra situações de perigo típicas. ${ }^{27}$ Como o reconhecimento de um dever de proteção decorre do monopólio do uso da força pelo Estado, é necessário também verificar as possibilidades de uma eficiente defesa autônoma por parte dos particulares.

Concluindo, podem ser apontados os seguintes topoi argumentativos como aptos a permitir o reconhecimento de um dever de proteção: a) a relação hierárquica abstrata e o peso concreto dos bens e interesses envolvidos (aqui, normalmente, a tutela da vida e da saúde ocupa uma posição

\footnotetext{
${ }^{24}$ NOVAIS, Jorge Reis. As restrições aos direitos fundamentais não expressamente autorizadas pela Constituição. Coimbra: Coimbra Editora, 2003, p. 93.

${ }^{25}$ CANARIS. Direitos fundamentais e direito privado. Tradução de Ingo Wolfgang Sarlet. Coimbra: Livraria Almedina, 2003, p. 102 e seg.

${ }^{26}$ Nesse sentido, CANARIS, Claus-Wilhelm. Direitos fundamentais e direito privado. Tradução de Ingo Wolfgang Sarlet. Coimbra: Livraria Almedina, 2003, p. 107-109.

${ }^{27}$ CANARIS. Direitos fundamentais e direito privado. Tradução de Ingo Wolfgang Sarlet. Coimbra: Livraria Almedina, 2003, p. 110.
} 
predominante em face da liberdade de iniciativa ou do direito de propriedade); b) o peso da intervenção e a intensidade da ameaça a referidos bens jurídicos; e c) a possibilidade de autoproteção do particular. ${ }^{28}$ Chega-se, assim, ao "sistema móvel" de critérios proposto por Canaris: "quanto maior o nível do direito fundamental afectado, quanto mais severa a intervenção que se ameaça, quanto mais intenso o perigo, quanto menores as possibilidades do seu titular para uma eficiente auto-protecção, e quanto menor o peso dos direitos fundamentais e interesses contrapostos, tanto mais será de reconhecer um dever jurídico-constitucional de protecção". ${ }^{29}$

A existência de deveres de proteção, na doutrina alemã, é associada principalmente, mas não exclusivamente, aos direitos fundamentais à vida, à integridade física e à saúde. ${ }^{30}$ Pode ser fundada em dispositivos constitucionais expressos $^{31}$ e também ser deduzida de normas que consagram direitos fundamentais, ${ }^{32}$ já que a simples consagração de um direito ou de um bem jurídico considerado valioso vincula o Estado no sentido de tutelá-lo.

A vinculação dos poderes públicos, relacionada com a dimensão objetiva dos direitos fundamentais, acarretou, portanto, uma mudança de perspectiva no tocante à compreensão de tarefas clássicas, como a edição de normas ou a atividade de polícia, ressaltando sua importância para a proteção e a plena eficácia dos direitos individuais.

\subsection{Direitos fundamentais e direito privado: algumas considerações}

A eficácia dos direitos fundamentais nas relações jurídicas privadas, por outro lado, tema recorrente na atualidade e ao qual se aludiu no tópico anterior, merece alguns desenvolvimentos.

Em primeiro lugar, tem-se que a afirmação de uma incidência de tais posições jurídicas nas relações entre particulares não pode significar a substituição do direito privado pelo público. Até porque a própria autonomia privada constitui um valor e um direito fundamental a ser tutelado.

\footnotetext{
${ }^{28}$ CANARIS. Direitos fundamentais e direito privado. Tradução de Ingo Wolfgang Sarlet. Coimbra: Livraria Almedina, 2003, p. 112 e seg.

${ }^{29}$ CANARIS. Direitos fundamentais e direito privado. Tradução de Ingo Wolfgang Sarlet. Coimbra: Livraria Almedina, 2003, p. 114.

${ }^{30}$ SARLET. A eficácia dos direitos fundamentais. Porto Alegre: Livraria do Advogado, 2003, p. 154

${ }^{31}$ No Brasil, podem-se extrair deveres de proteção das normas da CF/88 que consagram um direito à segurança (artigo $5^{\circ}$, caput), à proteção do consumidor (artigo $5^{\circ}$, inciso XXXII), um dever do Estado relativo à saúde (artigo 196) e o dever de estabelecer meios de defesa da pessoa e da família contra a propaganda de produtos, práticas e serviços que possam ser nocivos à saúde e ao meio ambiente (artigo 220, parágrafo $3^{\circ}$, inciso II), dentre outras disposições. Wilson Steinmetz (A vinculação dos particulares a direitos fundamentais. São Paulo: Malheiros, 2004, p. 129-130) aponta ainda as previsões dos artigos 50, inciso XLI, 227 e 230 da CF/88. Em Portugal, mencionem-se os deveres públicos de proteção do ambiente (artigo 66, n 2, da CRP) e da saúde, inclusive do consumidor (artigo 64, $\mathrm{n}^{\circ} 2$, e 60, $\mathrm{n}^{\circ} 1$, da mesma carta). Nesse sentido, examinar GONÇALVES, Pedro. Advertências da administração pública. In: AAVV. Estudos em homenagem ao Prof. Doutor Rogério Soares. Coimbra: Coimbra Editora, 2001, p. 778, nota 155. ${ }^{32}$ GONÇALVES, Pedro. Advertências da administração pública. In: AAVV. Estudos em homenagem ao Prof. Doutor Rogério Soares. Coimbra: Coimbra Editora, 2001, p. 778, nota 155.
} 
É defensável a aplicação direta dos direitos fundamentais nas hipóteses em que há desigualdade na relação (como é o caso das relações entre empregados e patrões ou entre o consumidor e fornecedores de bens e serviços), variando a intensidade da vinculação proporcionalmente ao grau de desigualdade ${ }^{33}$, ou quando há previsão expressa nesse sentido ${ }^{34}$. $O$ direito privado, porém, é que deve reger a relação em primeira linha, cabendo-Ihe concretizar a proteção decorrente da Constituição, dado o caráter "irradiante" dos direitos fundamentais para toda a ordem jurídica ${ }^{35}$. Somente no caso de lacuna, de inconstitucionalidade do direito ordinário e de lesão a aspectos fundamentais da personalidade, relacionados com a dignidade da pessoa, é que caberá sua aplicação direta.

Sob outra perspectiva, é possível afirmar que o cumprimento, pelo Estado, de deveres de proteção, materializado na elaboração de normas e na tutela de direitos fundamentais de particulares face a ameaças oriundas de outros particulares, constitui uma abordagem mais adequada do problema relacionado ao controle dos poderes privados e do abuso da autonomia individual. Com efeito, sem incidir em problemas que a tese que defende a vigência, de forma direta, dos direitos fundamentais nas relações jurídicas privadas traz, a teoria dos deveres de proteção pode chegar a resultados mais satisfatórios ${ }^{36}$. Não se vai aqui aprofundar o tema da eficácia (ou vigência) dos direitos fundamentais nas relações entre particulares ${ }^{37}$. Mas apenas ressaltar que a defesa da aplicação direta e imediata de normas de direitos fundamentais nas relações privadas, fora de situações de lesão flagrante ao princípio da dignidade da pessoa e de inconstitucionalidade ou inexistência de norma infra-constitucional que concretize um imperativo de proteção, ignora que do outro lado da relação se encontra um particular, também detentor de direitos fundamentais.

Afirmar que os direitos fundamentais podem ser aplicados, de forma ordinária, face a outros particulares, enfraquece a função de defesa de referidas

\footnotetext{
${ }_{33}$ PINTO, Paulo Mota. O direito ao livre desenvolvimento da personalidade. In: AAVV. Portugal-Brasil Ano 2000: tema direito, Coimbra: Coimbra Editora, 1999, p. 238.

${ }^{34}$ Como ocorre, na Lei Fundamental de Bonn, no seu artigo $9^{\circ}, n^{\circ} 3,2^{a}$ frase: "Se garante a todos e a todas as profissões o direito de constituir associações para a preservação e a melhora das condições laborais e econômicas. Serão nulos quaisquer pactos que restrinjam este direito ou tratem de obstaculizar-lo e ilícitas todas as medidas que proponha dito fim".

${ }^{35}$ Nesse sentido, Claus-Wilhelm CANARIS (Direitos Fundamentais e Direito Privado. Tradução de Ingo Wolfgang Sarlet. Coimbra: Livraria Almedina, 2003, p. 53-55), que defende a teoria da eficácia mediata dos direitos fundamentais em relação a terceiros, salvo exceções como a mencionada na nota anterior.

${ }^{36}$ Sobre o assunto, examinar NOVAIS, Jorge Reis (Os Direitos fundamentais nas relações jurídicas entre particulares, in Direitos Fundamentais - Trunfos contra a maioria. Coimbra: Coimbra Editora, 2006 , p. 69 seg).

${ }^{37}$ Dentre outros autores, mencionem-se UBILLOS, Juan María Bilbao. Los derechos fundamentales en la frontera entre lo público y lo privado: la noción de State action en la Jurisprudencia norteamericana. Madri: Mcgraw-Hill, 1997; PEREIRA, Jane Reis Gonçalves. Interpretação constitucional e direitos fundamentais. Rio de Janeiro: Renovar, 2006, p. 431 e seg.; STEINMETZ, Wilson. A vinculação dos particulares a direitos fundamentais. São Paulo: Malheiros, 2004; e a obra coletiva Constituição, direitos fundamentais e direito privado, organizada por Ingo Wolfgang SARLET. Porto Alegre: Livraria do Advogado, 2003.
} 
posições jurídicas, o que não ocorre quando se afirma que a sua aptidão natural é defender o indivíduo contra o Estado, já que este não pode invocar direitos fundamentais em seu favor. Por outro lado, a tese da aplicabilidade direta não prescinde da mediação estatal, já que, em última análise, quem vai reconhecer a incidência de um direito fundamental na relação será um órgão do Poder Judiciário. Também o próprio esquema da separação de poderes poderá ser atingido, já que a defesa de um ativismo judicial extremado em matéria de reconhecimento de direitos fundamentais nas relações privadas pode vir a desequilibrar o mencionado princípio, uma vez que incumbe por excelência ao legislador democraticamente eleito a instituição de mecanismos normativos e fáticos de defesa de direitos fundamentais de um particular face a outro. É certo que tal risco sempre estará presente quando se trata do controle jurisdicional da atuação e da omissão dos poderes públicos. Mas no caso de uma intervenção estatal, no intuito de concretizar um dever de proteção de um particular frente a outro, será mais fácil reconhecer e defender posições jurídicas dos particulares.

Lembre-se, ainda, o risco para a esfera da liberdade individual que a incidência rotineira e inflacionária dos direitos fundamentais traria, funcionalizando toda a existência e a dignidade humanas, e privando o indivíduo de uma zona de liberdade e mesmo de arbitrariedade legítima que decorre daquela dignidade. Em outras palavras, haveria a inversão da máxima segundo a qual "o que não está proibido é permitido". Não que o Estado não deva intervir, em primeiro lugar, por meio do legislador, e em segundo lugar, por meio do Judiciário, na tutela do indivíduo, por exemplo, contra discriminações ilegítimas e injustificáveis e violações ao princípio da igualdade, bem como contra abusos de particulares poderosos. Mas deve fazê-lo por meio de cumprimento de deveres de proteção - que se manifestam, por exemplo, na edição de leis contra discriminações no mercado de trabalho, de proteção do consumidor e de outros hipossuficientes.

\section{A TUTELA CONSTITUCIONAL DO CONSUMIDOR}

Neste ponto convém ressaltar o caráter jusfundamental da tutela dos consumidores. A proteção destes últimos se mostra necessária a partir da afirmação de relações econômicas de massa, típicas das sociedades industriais atuais. Mostra-se evidente a maior vulnerabilidade dos indivíduos diante de entidades poderosas, que detêm conhecimentos técnicos e recursos financeiros muito maiores. Tal proteção pode assumir duas vertentes, uma objetiva e outra subjetiva, mostrando-se interessante, para os fins da abordagem que se pretende fazer, comparar as cartas constitucionais brasileira e portuguesa.

Sob a perspectiva objetiva de tutela dos consumidores ${ }^{38}$, decorrem, em especial, deveres de proteção a cargo do Estado, seja por meio da legislação,

${ }^{38}$ ANDRADE, José Carlos Vieira de. Os direitos dos consumidores como direitos fundamentais na Constituição portuguesa de 1976, in Boletim da Faculdade de Direito da Universidade de Coimbra, v. 58, 2002, p. 46-47. 
da atuação administrativa e também do Poder Judiciário. ${ }^{39}$ Tal dimensão objetiva pode ser identificada, no Brasil, nos artigos 50, inciso XXXII, e 170, inciso $\mathrm{V}$, da CF/88, que deixam ampla margem de conformação ao legislador, sem configurar, de forma expressa, dimensões subjetivas. Por outro lado, há posições jurídicas individuais que permitem afirmar a existência de um radical subjetivo; no entanto, tais posições jurídicas revelam-se, na maior parte das vezes, como refrações dos direitos à vida, à saúde, à integridade física e à informação, dentre outros. ${ }^{40} \mathrm{Na}$ Constituição da República Portuguesa (CRP) há uma previsão de direitos específicos dos consumidores, em seu artigo 60, $n^{\circ} 1$, (direito à qualidade dos bens e serviços consumidos, à formação e à informação, à proteção da saúde, da segurança e dos seus interesses econômicos, bem como à reparação por danos). Mesmo a enunciação de tais direitos não afasta, porém, a ampla margem de conformação do legislador para os concretizar. ${ }^{41}$ Deve ser feita referência ainda à alínea "h" do artigo 81

${ }^{39} \mathrm{Na}$ Constituição da República Portuguesa, de início, a proteção do consumidor revestia-se de maior dimensão objetiva, já que no seu texto original, de 1976, era considerada uma incumbência prioritária do Estado, constante dos princípios gerais de sua organização econômica (artigo 81, alínea "m"). Proibia-se também a publicidade dolosa (artigo 109, n² 2). A Revisão de 1982 instituiu um capítulo específico para a proteção do consumidor, explicitando determinados direitos subjetivos, como os relativos à formação e à informação e à proteção da saúde, inseridos em seu artigo 110. Em 1989, os direitos do consumidor foram transferidos para a Parte III, alusiva aos direitos econômicos, sociais e culturais, especificamente para o artigo 60 de mencionada Carta constitucional. Sobre o tema, José Carlos Vieira de Andrade (Os direitos dos consumidores como direitos fundamentais na Constituição portuguesa de 1976, in Boletim da Faculdade de Direito da Universidade de Coimbra, v. 58, 2002, p. 43-44) e Carla Amado Gomes (Os novos trabalhos do Estado: a administração pública e a defesa do consumidor. Disponível em: <www.mundojuridico.adv.br/html/artigos/documentos/texto456.htm>. Acesso em 11 maio 2005). ${ }^{40}$ É de se mencionar que a CF/88, em seu artigo 37 , parágrafo $3^{\circ}$, inciso II, prevê que caberá à lei a disciplina da participação do usuário na administração pública direta e indireta, regulando especialmente as reclamações "relativas à prestação de serviços públicos em geral, asseguradas a manutenção de serviço de atendimento ao usuário e a avaliação periódica, externa e interna, da qualidade dos serviços". Os "direitos dos usuários" de serviços públicos serão também disciplinados por lei, como determina o inciso II do parágrafo único do artigo 175 de referida Constituição. É possível concluir que também quando se trata de serviços públicos, objeto de concessão ou permissão ou prestados diretamente pelo Estado, cabe aplicar as normas de proteção ao consumidor. Nesse sentido, José Geraldo Brito Filomeno (Dos direitos do consumidor. In: GRINOVER et al. Código de Defesa do Consumidor comentado pelos autores do anteprojeto, Rio de Janeiro: Forense Universitária, 2001, p. 22) e Zelmo Denari (Da qualidade de produtos e serviços, da prevenção e da reparação de danos. In: GRINOVER et al. Código de defesa do consumidor comentado pelos autores do anteprojeto, Rio de Janeiro: Forense Universitária, 2001, p. 175 e 193 e seg.).

${ }^{41}$ Nesse sentido, e considerando que nem todos os direitos previstos pelo artigo $60, n^{\circ} 1$, da CRP gozam do regime de proteção acrescida dos direitos, liberdades e garantias, examinar José Carlos Vieira de Andrade (Os direitos dos consumidores como direitos fundamentais na constituição portuguesa de 1976, in Boletim da Faculdade de Direito da Universidade de Coimbra, v. 58, 2002, p. 52-53). Um dos direitos que gozam de tal regime é o direito à reparação por danos. Considerando, por sua vez, que todos os direitos relativos aos consumidores têm a natureza de direitos, liberdades e garantias, examinar Carla Amado Gomes (Os novos trabalhos do Estado: a administração pública e a defesa do consumidor. Disponível em:

<www.mundojuridico.adv.br/html/artigos/documentos/texto456.htm>. Acesso em 11 maio 2005, p. 6). A autora fala em acumulação de posições jurídicas, de ordem substancial (proteção à integridade física, direito à informação), instrumental (formação e participação em associações de defesa do 
da CRP, que prevê como tarefa prioritária do Estado a defesa dos direitos e interesses dos consumidores. ${ }^{42}$

É possível falar, portanto, em uma acumulação de posições jurídicas fundamentais, ${ }^{43}$ uma vez que o consumidor pessoa física é um sujeito que já goza dos direitos à proteção de sua integridade física (artigos 24 e 25, $n^{\circ} 1$, da CRP e $5^{\circ}$, caput e inciso III, da CF/88), de sua propriedade (artigo 62, $\mathrm{n}^{\circ} 1$, da CRP e $5^{\circ}$, inciso XXII, da CF/88), de ser informado (artigo 37, n' 1 , da CRP e $5^{\circ}$, incisos IX, XIV, XXXIII e XXXIV, alínea "b", da CF/88), de associação e participação na vida pública (artigos $46, n^{\circ} 1$, e 48 da CRP e $5^{\circ}$, incisos XVII, XVIII e XXXIII e 37 , § $3^{\circ}$, da CF/88). Tais posições serão reforçadas e concretizadas por normas específicas de tutela dos consumidores eventualmente previstas no Texto Constitucional, como no caso do artigo 60, $n^{\circ} 1$, da CRP, bem como por diplomas normativos infraconstitucionais, mas assumem posição preeminente a garantia de um determinado nível de qualidade de produtos e serviços e, mais importante ainda, como condição para tal garantia, o fornecimento de informações adequadas acerca de referidos produtos e serviços.

O direito à informação, nessa perspectiva, a par de uma dimensão subjetiva, de cariz negativo, dirigido contra o Estado, com o fim de assegurar o acesso a informações, reveste uma dimensão objetiva e positiva, impondo aos poderes públicos o estabelecimento de regras acerca do conteúdo e das formas de cumprimento do dever de informar por parte dos sujeitos econômicos. ${ }^{44}$ Trata-se de um dever de proteção imposto ao Estado, que, no Brasil, se vai especializar nas disposições constantes do inciso II do $\S 3^{\circ} \mathrm{e}$ do $\S 4^{\circ}$ do artigo 220 da CF/88.

O referido dever de proteção se vai materializar não apenas nas normas específicas destinadas a disciplinar a relação entre consumidores e fornecedores de bens e serviços, pelas quais se estabelecem deveres informativos para estes últimos, mas também na emissão de advertências e na restrição da publicidade de produtos, práticas e serviços que possam ser nocivos à saúde e ao meio ambiente, bem como de tabaco, bebidas

consumidor) e de reparação de danos. O caráter de direitos, liberdades e garantias dos direitos dos consumidores decorre da circunstância de serem concretizações de posições jurídicas já consagradas com referido status, como é o caso dos direitos à vida e à integridade física e a ser informado.

${ }^{42} \mathrm{Em}$ Portugal, a defesa do consumidor não é apenas uma tarefa do Estado, por imposição constitucional, mas exsurge também como obrigação a ser prosseguida no quadro do Direito Comunitário. Examinar, nesse sentido, os artigos $3^{\circ}, n^{\circ} 1$, "t", e 153 do Tratado da União, com as alterações do Tratado de Amsterdan.

${ }^{43}$ GOMES, Carla Amado. Os novos trabalhos do Estado: a administração pública e a defesa do consumidor. Disponível em:

<www.mundojuridico.adv.br/html/artigos/documentos/texto456.htm>. Acesso em 11 maio 2005, p. 6-7.

${ }_{44}$ GOMES, Carla Amado. Os novos trabalhos do Estado: a administração pública e a defesa do consumidor. Disponível em: <www.mundojuridico.adv.br/html/artigos/documentos/texto456.htm>. Acesso em 11 maio 2005, p. 7. 
alcoólicas, agrotóxicos, medicamentos e terapias. ${ }^{45}$ É aqui que deve ser inserido também o dever imposto à União, aos Estados, aos Municípios e ao Distrito Federal, decorrente do $\S 3^{\circ}$ do artigo 10 do CDC, de informarem os consumidores sempre que tiverem conhecimento da periculosidade de produtos ou serviços à saúde ou à segurança. Referido dever assume uma perspectiva mais ampla do que a tutela dos consumidores, por não incidir especificamente sobre as relações por eles mantidas com os fornecedores de tais produtos e serviços, mas por se destinar a proteger a sociedade globalmente considerada. Em Portugal, por sua vez, as restrições à publicidade de determinados produtos, bem como as advertências administrativas sobre seus malefícios ou inconvenientes, parecem decorrer de forma mais direta das normas de tutela dos consumidores (artigo 60, $n^{\circ} 2$, da CRP). ${ }^{46}$

\section{EXISTÊNCIA OU NÃO DE UM DIREITO SUBJETIVO A UMA MEDIDA DE PROTEÇÃO E O PRINCÍPIO DA PROIBIÇÃO DE INSUFICIÊNCIA}

Os deveres de proteção impostos ao Estado podem ser enquadrados dogmaticamente de duas formas: como a outra "face" de um eventual direito subjetivo dos indivíduos à proteção ou à segurança ou como conseqüência "jurídica dos conteúdos objetivos positivos dos direitos fundamentais".

Parece mais adequada a segunda perspectiva, uma vez que, diante da ampla margem de conformação detida pelo legislador, a regra é que não se encontram definidas na Constituição as medidas de proteção que devem ser adotadas. Salvo uma previsão expressa de uma determinada ou determinável ação de prevenção ou de proteção, ou uma violação do nível mínimo de proteção que se possa extrair com suficiente densidade de uma imposição de realização objetiva de um direito fundamental, que permitisse "reduzir a zero" o espaço de discricionariedade do legislador, descabe falar em "direito a proteção". ${ }^{48}$ Por outras palavras, se é possível extrair da Constituição um "se" acerca da existência ou não de deveres de proteção, na maior parte das vezes pouco se pode obter em termos de "como" e "quando" tal proteção

\footnotetext{
${ }^{45}$ Paulo Luiz Netto Lôbo (A informação como direito fundamental do consumidor. In Estudos de Direito do Consumidor, n. 3, Coimbra, Centro do Direito do Consumo, 2001, p. 27) caracteriza corretamente o direito à informação dos consumidores como oponível a todo aquele que fornece produtos e serviços no mercado de consumo, não se dirigindo contra o poder político, mas sim contra o agente da atividade econômica. Posteriormente (op. cit., p. 29), identifica deveres impostos ao Estado no sentido de assegurar a realização dos direitos dos consumidores, o que implica o estabelecimento de organizações e procedimentos, além da edição de normas e do exercício de atividades de fiscalização e de resolução de conflitos.

${ }^{46}$ Nesse sentido, ANDRADE. Os direitos dos consumidores como direitos fundamentais na Constituição portuguesa de 1976, in Boletim da Faculdade de Direito da Universidade de Coimbra, v. 58,2002 , p. 57.

${ }^{47}$ NOVAIS, Jorge Reis. As restrições aos direitos fundamentais não expressamente autorizadas pela Constituição, p. 86-87.

${ }^{48}$ HESSE, Konrad. Elementos de direito constitucional da República Federal da Alemanha, Porto Alegre: Sérgio Antônio Fabris Editor, 1998, p. 279-280; NOVAIS. As restrições aos direitos fundamentais não expressamente autorizadas pela Constituição, p. 89-90; SARLET, Ingo Wolfgang. A eficácia dos direitos fundamentais, p. 203.
} 
será efetuada. É reconhecido, em conseqüência, um papel importante ao legislador.

Em regra, os imperativos de tutela decorrentes da Constituição impõem apenas um dado resultado que se pretende obter, não uma conformação específica. Caso houvesse uma predeterminação constitucional completa de um dever de proteção, descaberia, a rigor, falar em proibição de insuficiência, mas, na maioria dos casos, deve ser verificado se a proteção satisfaz exigências mínimas de eficiência e se os interesses e bens jurídicos contrapostos não estão sobreavaliados. Para isso, impõe-se examinar o direito ordinário (civil, penal, administrativo etc.) e proceder a uma "nova ponderação" entre os direitos fundamentais e bens jurídico-constitucionais em jogo. ${ }^{49}$

Em problemas pluridimensionais de liberdade, a incidência do princípio de proibição de insuficiência, na verdade, pouco acrescentará ao que já decorre do princípio da proibição de excesso.$^{50}$ Nessas situações, tem-se dois direitos fundamentais em colisão: por exemplo, a liberdade de iniciativa ou de expressão (i), de um lado, e o direito à saúde (ii) de outro, o qual leva à adoção de uma medida de proteção (M1). Ora, afirmar que o exercício de (i) é afetado desproporcionalmente por (M1), o que reflete a aplicação do princípio da proibição de excesso, ou que (M1) deve ser praticada para se proteger adequadamente o bem jurídico tutelado por (ii), havendo uma intervenção gravosa no seu âmbito de proteção por parte de (i), sob pena de ser reconhecido um défice de tutela, são duas faces da mesma moeda. Sob outra perspectiva, o titular de (i) pode afirmar que há um défice na tutela do referido direito e um excesso na proteção de (ii) por meio de (M1) e exigir uma abstenção do Estado. O titular de (ii), por sua vez, também pode afirmar o mesmo em relação ao seu direito, mas para exigir a adoção de (M1).

Trata-se de uma conseqüência objetiva das "diferentes perspectivas de análise da colisão por parte dos titulares dos direitos fundamentais e consoante está em causa, respectivamente, um dever de omissão ou um dever de acção estatal". ${ }^{51}$ A resolução de tal conflito leva necessariamente a uma ponderação, que observe os princípios da proibição de excesso e da necessidade ou indispensabilidade.

Pode-se reconhecer, no entanto, alguma autonomia e utilidade no princípio da proibição de insuficiência. Não, porém, no momento de ponderação, pelo legislador, dos bens e direitos em conflito, mas no momento posterior do

49 Examinar, a propósito, CANARIS, Claus-Wilhelm. Direitos fundamentais e direito privado, p. 123-125.

${ }^{50}$ Nesse sentido, J. J. Gomes Canotilho afirma que a proibição de défice não explica por si só a exigência definitiva de uma atuação estatal, não se mostrando certa a sua autonomia ante o princípio da proporcionalidade e a necessidade de ponderação de bens em conflito (Omissões normativas e deveres de protecção. In: AAVV. Estudos em homenagem a Cunha Rodrigues, v. 2. Coimbra: Coimbra Editora, 2001, p. 118).

${ }^{51}$ NOVAIS, Jorge Reis. As restrições aos direitos fundamentais não expressamente autorizadas pela Constituição, p. 78, nota 103. 
controle de referida ponderação por parte do Judiciário, em especial do Juiz Constitucional. Importa aqui determinar se foi ou não violado um "patamar mínimo de obrigatoriedade de realização de um direito fundamental", o qual não se situa dentro da margem de discricionariedade do legislador. A omissão deste último, ao não adotar uma medida suficiente ou ao adotar uma medida insuficiente, é vista como uma restrição de um direito fundamental carecedor de tutela, o que apresenta o problema de definir se o Judiciário terá um controle pleno sobre a ponderação realizada pelos representantes eleitos e se poderá ser configurado um direito subjetivo a uma concreta e específica medida de proteção. ${ }^{52}$

Impondo-se ao Estado, e precipuamente ao legislador, a realização de ponderações e de juízos de prognose quanto às medidas a adotar nos casos em que há problemas pluridimensionais de liberdade, de forma a harmonizar e compatibilizar os direitos fundamentais de sujeitos diversos, o máximo que se poderá afirmar, em termos de pretensões subjetivas de prima facie, é a possibilidade de exigir dos poderes públicos que sua discricionariedade seja adequadamente exercida e que as medidas adotadas não sejam "completamente inidóneas ou insuficientes". 53

Muito embora a "justiciabilidade" ou a "judiciabilidade" apresente-se como elemento hábil a identificar a existência de um direito subjetivo, ela não é o único. $^{54}$ Isso porque somente quando a possibilidade do particular acionar o Judiciário no sentido de ver reconhecido um interesse próprio, autônomo e individualizado estiver presente é que se poderá falar em direito subjetivo, pelo menos segundo uma visão tradicional. ${ }^{55}$ Entre o reconhecimento de um mero dever objetivo imposto ao Estado até uma posição configurável como direito subjetivo, pelo menos nesse sentido estrito, existem diversas posições intermediárias, com diferentes níveis de consistência e graus de exigibilidade. Assim, é possível identificar a possibilidade de um controle mais objetivo, levado a cabo por órgãos ou entidades específicos, como o Ministério Público ou associações por exemplo, de forma a fazer valer direitos e interesses que não se possam individualizar, como os interesses difusos. Ademais, é possível

\footnotetext{
52 NOVAIS, Jorge Reis. As restrições aos direitos fundamentais não expressamente autorizadas pela Constituição, p. 78-79, nota 103.

${ }^{53}$ NOVAIS, Jorge Reis. As restrições aos direitos fundamentais não expressamente autorizadas pela Constituição, p. 95.

${ }^{54}$ A noção de direito subjetivo, herdada do direito civil, normalmente gravita ao redor das idéias de Savigny e de Jhering: para o primeiro, direito subjetivo é um poder da vontade; para o segundo, um interesse juridicamente protegido. Alude-se, ainda, à posição mista ou eclética de Jellinek, como um bem ou interesse protegido por um poder da vontade. E também à concepção de Jean Dabin, de direito subjetivo como uma pertença-domínio. Nesse sentido, Fredie Didier Jr. e Hermes Zaneti Jr. (Curso de direito processual civil: processo coletivo, Salvador: Juspodium, 2007, v. 4, p. 88 e 262). Um autêntico direito subjetivo deve ensejar a seu titular a possibilidade de buscar a tutela jurisdicional plena no sentido de proteger as faculdades que o integram.

${ }^{55}$ Nesse sentido, NOVAIS, Jorge Reis. As restrições aos direitos fundamentais não expressamente autorizadas pela Constituição, p. 101 e seg., e Andrade, José Carlos Vieira de. A justiça administrativa, Coimbra: Livraria Almedina, 2000, p. 81.
} 
reconhecer legitimidade processual sem que exista uma posição jurídica substantiva, desde que a decisão do processo repercuta favoravelmente no tocante à defesa da esfera jurídica de titulares de meros interesses de fato. ${ }^{56}$

Nessa perspectiva, pode-se examinar a decisão proferida pelo Tribunal Regional Federal da $4^{\mathrm{a}}$ Região, na Apelação Cível 2002.04.01.000611-1/PR ${ }^{57}$, mantida pelo Superior Tribunal de Justiça, no Recurso Especial 772.723/PR.

Trata-se de ação civil pública movida contra a União Federal e a Associação Brasileira de Bebidas, antes da edição da Lei nº 9.294/96, por uma associação de defesa dos consumidores pleiteando, dentre outros pedidos, a condenação dos réus a fazer constar na publicidade de bebidas alcoólicas, de forma clara e ostensiva, advertência acerca dos riscos e potenciais danos à saúde decorrentes de seu consumo, bem como a correta rotulagem de referidos produtos.

A sentença de primeira instância julgou improcedentes os pedidos. Considerou que o Judiciário não poderia impor aos fabricantes de bebidas a veiculação de advertências sem que o seu teor esteja previsto em lei e que a norma então vigente, o CDC, não continha previsão nesse sentido. ${ }^{58}$

Em sede de recurso, a entidade promotora da ação, além de repetir seus argumentos iniciais, pleiteou a declaração incidental de inconstitucionalidade do parágrafo único do artigo $1^{\circ}$ da Lei no 9.294/96, posteriormente editada. O Tribunal Regional Federal da $4^{\mathrm{a}}$ Região, ao apreciar o recurso de apelação referido, deu a ele provimento parcial, determinando restrições à publicidade de bebidas alcoólicas, em especial advertências, além daquelas previstas na legislação de regência.

Subjacente à discussão posta em juízo, tem-se o parágrafo único do artigo $1^{\circ}$ da Lei $n^{\circ} 9.294 / 96$, que define como bebidas alcoólicas, para os efeitos do citado diploma legal, apenas as que tenham concentração de álcool superior a treze graus Gay Lussac, dispositivo que suscitou críticas por deixar sem qualquer restrição a publicidade de cervejas e da maioria dos vinhos. ${ }^{59}$

\footnotetext{
${ }^{56}$ ANDRADE, José Carlos Vieira de. A justiça administrativa, p. 86-87.

57 A Relatora foi a Desembargadora Federal Marga Inge Barth Tessler. O voto nele proferido pela Relatora pode ser obtido no sítio da referida corte (Disponível em: <www.trf4.gov.br>).

${ }^{58}$ O Supremo Tribunal Federal já havia examinado o tema na ADIn 1.755-DF (Relator Ministro Nelson Jobim, decisão publicada no Diário da Justiça da União, 18 maio 2001), pela qual se impugnava a definição de bebida alcoólica efetuada pela Lei no 9.294/96. A Corte Maior não conheceu da Ação Direta, sob o fundamento de se tratar de matéria que deve ser dirimida no âmbito do Congresso Nacional, não podendo o Supremo Tribunal Federal atuar como legislador positivo.

${ }^{59}$ As restrições ao consumo e à venda de bebidas alcoólicas em Portugal se encontram no Decreto-Lei no 9/2002, de 24 de janeiro. Na exposição de motivos que o acompanha, se reconhece o aumento do consumo de mencionadas bebidas, sobretudo entre jovens, como um sério problema de saúde pública, mencionando-se a influência exercida pela publicidade na iniciação no consumo de álcool. O referido diploma, porém, não regula as restrições à publicidade do produto, matéria deixada para o Código da Publicidade. Em seu artigo 1º , define como bebida alcoólica, para os fins do referido decreto-lei, toda aquela que, por fermentação, destilação ou adição, contenha um título alcoométrico superior a $0,5 \%$ vol.
} 
Para as demais bebidas, prevê o artigo $4^{\circ}$ do mencionado diploma que a propaganda comercial no rádio e na televisão pode ser veiculada apenas entre as vinte e uma e as seis horas. Não poderá ela associar o produto ao esporte olímpico ou de competição, ao desempenho saudável de qualquer atividade, à condução de veículos e a imagens ou idéias de maior êxito ou sexualidade das pessoas. Por fim, prevê-se que os rótulos das embalagens de bebidas alcoólicas deverão conter advertência nos seguintes termos: "Evite o Consumo Excessivo de Álcool". 60

Verifica-se que referidos dispositivos consagram duas ponderações distintas: a) no artigo $4^{\circ}$, ao prever medidas restritivas mais brandas para a publicidade de bebidas alcoólicas do que as estabelecidas para produtos fumígeros; b) no artigo $1^{\circ}$, parágrafo único, ao afastar de tais restrições determinadas bebidas que contenham teor alcoólico de até treze graus Gay Lussac.

O Tribunal Regional Federal da $4^{\mathrm{a}}$ Região afastou o argumento de não ser possível ao Judiciário impor a veiculação de uma mensagem como a pretendida sob o argumento de faltar fundamento legal para tanto e sem que o teor da mensagem esteja previsto em lei. Argumentou-se com a necessidade de se dar plena concreção às políticas públicas previstas na Constituição, que vinculam o legislador e o Judiciário, reduzindo sua discricionariedade decisória, e que a tutela da saúde tem relevância pública, tal como decorre dos artigos 196 e 197 da CF/88. Por outro lado, a previsão constitucional de tutela do consumidor e de estabelecimento de restrições à publicidade de bebidas (artigos 170 , inciso $\mathrm{V}$, e 220 , parágrafo $3^{\circ}$, inciso II, e parágrafo $4^{\circ}$, da CF/88) abre a possibilidade de plena "justiciabilidade" da matéria. A Lei no 9.294/96 não teria encerrado a questão, que pode ser discutida tanto sobre o aspecto sanitário quanto sob a perspectiva dos direitos dos consumidores. Ante o reconhecimento da nocividade do álcool para a saúde, da relação de causa e efeito entre seu consumo excessivo e a ocorrência de acidentes de trânsito, do seu potencial gerador de dependência química, da necessidade de se proteger crianças e adolescentes da publicidade do produto e do direito dos cidadãos, como consumidores, a serem informados, foi afirmada a necessidade de uma informação clara, precisa e ostensiva acerca de referidos malefícios, invocando-se também o teor do artigo $9^{\circ}$ do CDC. ${ }^{61}$

\footnotetext{
${ }^{60}$ Em Portugal, o artigo 17 do Código da Publicidade trata indistintamente de todas as bebidas alcoólicas, proibindo a veiculação de propaganda na televisão e no rádio entre as sete e as vinte e uma horas e trinta minutos. Ademais, para ser lícita, a publicidade deve observar uma série de restrições contidas no $n^{\circ} 1$ de referido dispositivo, tais como não se dirigir a menores, nem apresentá-los consumindo tais bebidas, não encorajar consumos excessivos, não menosprezar os não-consumidores, não sugerir êxito social ou especiais aptidões por efeito do consumo, não associar o consumo de tais bebidas ao exercício físico ou à condução de veículos, dentre outras. ${ }_{61} \mathrm{O}$ qual determina que o "fornecedor de produtos e serviços potencialmente nocivos ou perigosos à saúde ou segurança deverá informar, de maneira ostensiva e adequada, a respeito da sua nocividade ou periculosidade, sem prejuízo da adoção de outras medidas cabíveis em cada caso".
}

DiREITOS FundaMeNTAIS E E JUSTIÇA - ANO 5, N 15, P. 79-105, ABR./Jun. 2011 
A edição da Lei $n^{\circ}$ 9.294/96 foi considerada um reconhecimento parcial do pedido da entidade autora. Não foi, porém, proferido julgamento quanto à sua inconstitucionalidade, muito embora tenha sido reconhecida a inexistência de razoabilidade e de proporcionalidade de suas disposições no tocante ao produto referido, francamente favoráveis à indústria, ao desviar-se do cumprimento de políticas públicas decorrentes da Constituição no que diz respeito à saúde, à proteção e à informação ao consumidor e ao classificar como alcoólicas somente as bebidas cuja concentração de referida substância ultrapassa treze graus Gay Lussac. Acolheu-se parcialmente o pedido, para o fim de obrigar a veiculação não das mensagens pretendidas pelo autor, mas sim de um alerta básico, em expressão gráfica "adequada", afastando-se o uso de letras minúsculas e de inserções visuais rápidas no caso de comerciais pela televisão, do qual conste o real teor alcoólico da bebida, que seu consumo em excesso pode causar dependência, que não deve ser consumida por gestantes e de que é proibida sua venda a menores de dezoito anos. A Associação Brasileira de Bebidas foi condenada a realizar publicidade institucional aos seus associados e ao público sobre o assunto por um período de seis meses e a União Federal foi condenada a orientar seus órgãos sanitários e do consumidor no sentido de veicular anúncios acerca dos malefícios do consumo de bebidas alcoólicas. Os efeitos da decisão foram suspensos até o seu trânsito em julgado, tendo os réus oferecido recursos especial e extraordinário.

O Superior Tribunal de Justiça, por decisão monocrática do Relator, Ministro Benedito Gonçalves, ao apreciar o RESP 772.723, manteve o acórdão do TRF da $4^{\mathrm{a}}$ Região, restringindo, porém, sua eficácia ao âmbito de jurisdição do órgão prolator do decisum. Agravo regimental deduzido contra essa decisão não foi provido, tendo o feito sido encaminhado ao Supremo Tribunal Federal, para apreciar o Recurso Extraordinário (RE 614162, Relator Ministro Celso de Mello), ainda não julgado até esta data.

Ressalte-se que a decisão proferida em segunda instância parece adequada. Apesar de nela não se fazer expressa referência ao princípio da proibição de insuficiência, foram formuladas considerações acerca do défice de proteção exsurgente dos dispositivos legais atacados aos direitos à saúde, à informação e à proteção do consumidor. Foi também verificado se os direitos fundamentais envolvidos encontravam-se adequadamente sopesados e se não foi dada uma preferência desproporcional a algum deles. Por um lado, tem-se a liberdade de iniciativa e a liberdade de expressão dos produtores de bebidas alcoólicas; de outro, os direitos à saúde, à vida e à informação das pessoas. À luz dos princípios da proporcionalidade, especialmente na sua vertente de proibição de excesso, e da proibição de défice ou insuficiência, é possível também concluir pelo acerto da mencionada decisão e submetê-la a uma "releitura" pela qual se busque explicitar a aplicação das aludidas pautas de conduta.

Nesse sentido, tem-se, inicialmente, que a exclusão do alcance das medidas restritivas das bebidas dotadas de menor teor de álcool não parece justificável. 
Não há fundamento racional para não submetê-las às restrições unicamente com base na quantidade de referida substância. Os potenciais danos à vida e à saúde são idênticos caso sejam ingeridas bebidas com maior ou com menor graduação alcoólica. Basta consumir-se maior quantidade destas últimas para se obterem os mesmos efeitos. Ressalte-se que a intoxicação por bebidas de menor teor alcoólico, como as cervejas, é responsável por grande número de acidentes de trânsito e também por causar dependência e outras doenças; ou seja, foi levado em consideração um elemento manifestamente impertinente para se estabelecer um "benefício" para as bebidas de menor graduação alcoólica, à luz do fim que se pretende obter (a tutela da saúde e da vida). A rigor, poderia ser mesmo alegado que foi consagrada uma lesão ao princípio da igualdade, já que há um tratamento injustificadamente menos gravoso para as bebidas de menor concentração de álcool.

Em segundo lugar, tem-se que as liberdades de iniciativa e de expressão foram excessivamente privilegiadas em detrimento dos direitos à saúde e à informação, os quais, por sua vez, sofreram um dano não negligenciável. A rigor, inexiste qualquer medida de proteção de referidos direitos contra a publicidade de bebidas de menor teor alcoólico. Há aqui, portanto, a incidência do princípio da proibição de excesso e também do princípio da proibição de insuficiência, como sua contraface, considerando a sobrevaliação das duas primeiras liberdades, com uma incidência gravosa desproporcional sobre os dois últimos direitos. A obrigação de veicular advertências mostra-se a medida menos onerosa, uma vez que mantém integralmente a liberdade de iniciativa e de fazer publicidade. Constitui um dado adquirido o fato de que é imprescindível assegurar-se 0 acesso a diferentes fontes e opiniões de forma a possibilitar que as pessoas sejam melhor informadas e ajam de maneira mais responsável. ${ }^{62}$ Nessa perspectiva, a vedação da publicidade de bebidas alcoólicas seria medida bem mais gravosa, por impedir a expressão de idéias contrárias a respeito do produto, suprimindo um debate que poderia ser enriquecedor para a esfera pública.

\footnotetext{
${ }^{62}$ Sobre o tema, examinar Jónatas Machado (Liberdade de expressão: dimensões constitucionais da esfera pública no sistema social. Coimbra: Coimbra Editora, 2002 p. 476) e Ronald Dworkin (Sovereign virtue: the theory and practice of equality, Cambridge: Harvard University Press, 2000, p. 374-375). David A. Strauss (Persuasion, autonomy, and freedom of expression. Columbia Law Review, v. 91, 1991, p. 364-365) critica o denominado princípio da persuasão, associado à liberdade de expressão nos Estados Unidos da América, pelo qual o Governo não pode restringir o discurso em razão das conseqüências que ele provoca, podendo, porém, oferecer "mais discurso" (more speech), para corrigir o caráter manipulador de determinadas formas de expressão. Para o autor referido, "mais discurso", como o oferecimento de contra-argumentos ou a realização de publicidade negativa, nem sempre é um remédio adequado, pois, em um mundo em que os recursos são limitados, tais medidas são custosas, além de nem sempre se mostrarem efetivas. Defende, por outro lado, que se pode restringir o discurso de particulares, sobretudo quando os perigos dele decorrentes superarem os perigos de permitir uma restrição de modalidades expressivas manipuladoras da conduta.
}

DiREITOS FundAMENTAIS E E JUSTIÇA - ANO 5, N 15, P. 79-105, ABR./JUn. 2011 
A ponderação efetuada pelo legislador brasileiro foi, portanto, nitidamente inadequada, em virtude de não ter atribuído o peso ou a importância devidos aos bens e interesses em conflito. Com efeito, após a identificação de quais valores, direitos ou bens outros colidem entre si (primeira etapa do procedimento de ponderação), há de se argumentar sobre o grau de cumprimento de uns e sobre o nível de descumprimento ou prejuízo de seus contrários, que é a segunda etapa de mencionado procedimento. ${ }^{63}$ Para tanto, podem-se adotar argumentos de fato, extraídos das circunstâncias do caso, e também argumentos de direito. Esclareça-se que o que se pondera são direitos, valores ou interesses protegidos, não fatos. Destes últimos, porém, podem ser retirados argumentos que servirão para demonstrar o grau de atendimento a bens ou direitos ou de prejuízo a outros. ${ }^{64}$

Como argumentos de fato que devem ser lembrados, tem-se o aumento do consumo de bebidas alcoólicas no Brasil, sobretudo cervejas, bem como da sua ingestão abusiva, a relevância do álcool como fator de internação em clínicas psiquiátricas, a associação entre a bebida e acidentes de trânsito e a criminalidade violenta, o impacto da substância na saúde humana e nas relações sociais e a relação entre publicidade e aumento de seu consumo. ${ }^{65}$ Ressalte-se que a publicidade de bebidas de teor alcoólico de até treze graus Gay Lussac é tratada, sob a perspectiva legal, da mesma forma que a publicidade de bebidas que não contêm álcool, como leite e sucos, e é submetida apenas a uma auto-regulação por meio do Código Brasileiro de Auto-Regulamentação Publicitária e pela atividade de arbitramento do CONAR (Conselho Nacional de Auto-Regulamentação Publicitária). Tal auto-regulação não tem sido

\footnotetext{
${ }^{63}$ Nesse sentido, SANTIAGO, José Maria Rodríguez de. La ponderación de bienes e interesses en el derecho administrativo, p. 130.

${ }^{64}$ SANTIAGO, José Maria Rodríguez de. La ponderación de bienes e interesses en el derecho administrativo, p. 134.

${ }^{65}$ Examinar, a propósito, Sebastião Moreira Jr. (A regulação da publicidade das bebidas alcoólicas. Disponível em: <www.senado.gov.br/web/conleg/textos_discussao/texto\%2020\%20-20sebastiao.pdf>. Acesso em 10 maio 2005). O autor menciona estudo domiciliar realizado em 2001 em cento e sete cidades brasileiras, envolvendo 8.589 entrevistados, no qual se constatou o uso de álcool ao longo da vida por $77,3 \%$ da população masculina e por $60,6 \%$ da população feminina. Tais percentuais foram de $52,2 \%$ e $44,7 \%$, respectivamente, para a faixa etária abaixo de 18 anos, apesar da proibição de venda. Considerando todos os indivíduos acima de 12 anos de idade, constatou-se que $11,2 \%$ apresentam dependência do produto. Outros estudos, realizados entre 1987 e 1997, constataram um aumento substancial no abuso do álcool por parte de estudantes do ensino fundamental e médio de dez capitais brasileiras, que passou de 5,6\% para 9,4\%, sendo que a cerveja apareceu como a bebida mais consumida ( $70 \%$ dos estudantes que bebiam). Estudo comparativo da OMS, envolvendo 153 países, situou o Brasil na $63^{\mathrm{a}}$ posição entre os maiores consumidores per capita de álcool na faixa etária de 15 anos, aparecendo a cerveja como a bebida mais consumida (54 litros per capita ao ano). $\mathrm{O}$ consumo de referida bebida tem aumentado de 3\% a 5\% ao ano no País. Outros dados: $90 \%$ das internações em virtude de consumo de substâncias psicoativas decorrem do álcool, e 27,2\% das vítimas de acidentes de trânsito apresentavam teor da substância no sangue superior ao permitido pelo Código Nacional de Trânsito. Exame dos laudos de necrópsias elaborados pelo Instituto Médico Legal de São Paulo, no período de 1987 a 1992, concluiu que 15,2\% dos casos apresentavam alcoolemia, o que permite uma associação entre o consumo da substância e o aumento da criminalidade.
} 
suficiente para evitar apelos publicitários cada vez mais agressivos, fundados em exploração do erotismo e em associações com esportes de massa, principalmente o futebol, de grande sucesso entre o público jovem. Tais circunstâncias, além de justificarem um elevado número de disputas levados ao CONAR, também suscitaram a apresentação de nove projetos de lei no Congresso Nacional, destinados a disciplinar a matéria, mas não apreciados até o momento. ${ }^{66}$

Como argumentos jurídicos, é de se lembrar a maior proximidade entre os direitos à saúde e à informação do consumidor e a idéia de dignidade da pessoa, se em comparação com as liberdades de iniciativa e de efetuar publicidade, a falta de razoabilidade da exclusão das bebidas de menor teor alcoólico, além da ponderação prévia efetuada pela CF/88, em seu artigo 220, $\S 3^{\circ}$, inciso II, e $\S 4^{\circ}$, que aponta para uma prevalência do direito à saúde e para a existência de um dever de proteção contra os malefícios decorrentes da publicidade de determinados produtos e serviços, por meio da veiculação de advertências, "sempre que necessário".

Não se trata, repita-se, de uma hierarquização rígida e fechada, mas sim de uma preferência prima facie estabelecida pela CF/88 e que aponta para um determinado sentido, no caso, a prioridade, a princípio, dos direitos à saúde, à vida e à informação ante o direito de efetuar publicidade de bens e serviços. A aplicação da metodologia da ponderação afirma-se como meio de solucionar conflitos entre direitos fundamentais, do mesmo ou de diferentes titulares, e entre direitos e bens jurídicos da comunidade, principalmente quando não se encontra uma solução para referidas colisões no Texto Constitucional ${ }^{67}$ e na lei. Mesmo quando for estabelecida uma preferência pelo constituinte, porém, caberá a realização de ponderações ante a inexistência de uma ordem hierárquica de todos os bens e valores e ante a necessidade de considerar não apenas a pauta normativa abstrata, mas também o caso concreto. A prioridade eventualmente fixada pelo constituinte não afasta a possibilidade de se fazer ceder, por exemplo, a saúde e o direito à informação dos consumidores ante as liberdades de iniciativa e de expressão, bem como de efetuar publicidade, dos produtores e comerciantes. Para que tal ocorra, entretanto, exige-se uma especial carga argumentativa. Assim, seria necessário argumentar-se com maior rigor para se afastar a publicidade de bebidas da sujeição a referidas restrições. O legislador, porém, não se desincumbiu de tal ônus. Aliás, nem poderia fazê-lo, ante a falta de razoabilidade da decisão por ele adotada.

O estabelecimento de prevalências prima facie, como a que parece decorrer do $\S 4^{\circ}$ do artigo 220 da CF/88, não leva, portanto, ao afastamento

\footnotetext{
${ }^{66}$ MOREIRA JR. A regulação da publicidade das bebidas alcoólicas. Disponível em: $<w w w . s e n a d o . g o v . b r / w e b / c o n l e g / t e x t o s \_d i s c u s s a o / t e x t o \% 2020 \% 20-20$ sebastiao.pdf>. Acesso em 10 maio 2005, p. 19 e seg.

${ }^{67}$ A propósito, conferir LARENZ, Karl. Metodologia da ciência do direito, p. 490-491.
} 
da necessidade de se ponderar, já que não concretiza uma regra, passível de aplicação subsuntiva, mas sim uma orientação de a qual resultado poderá chegar a ponderação. Isso porque o constituinte jamais poderia prever toda a diversidade com que conflitos entre direitos podem surgir. Raramente será hipótese de a totalidade de um direito colidir com outro. O mais comum é, como visto, que, na riqueza das situações concretas, uma parcela do direito ou uma modalidade de seu exercício choque-se com um aspecto parcelar de outro bem ou direito, o que poderá levar a soluções diversas de acordo com as peculiaridades do caso.

Chega-se, assim, à terceira fase do procedimento de ponderação, aquela em que se faz prevalecer um direito ou interesse ante outro, como resultado das argumentações efetuadas anteriormente.$^{68}$ Os direitos à vida, à saúde e à informação devem fazer ceder as liberdades de iniciativa e de expressão, para o fim de sujeitar a restrições a publicidade de todas as bebidas alcoólicas, principalmente por meio de veiculação de mensagens informativas que advirtam para os perigos de seu consumo; pelo menos quando tal for estritamente necessário, ante as circunstâncias de fato já apontadas, e inexistirem outros meios menos gravosos capazes de assegurar uma proteção adequada aos bens jurídicos referidos. As restrições quanto ao horário e ao conteúdo da publicidade, previstos no caput e no $\S 1^{\circ}$ do artigo $4^{\circ}$ da Lei $n^{\circ} 9.294 / 96$, devem ser aplicadas também no tocante à publicidade de bebidas cuja concentração de álcool seja inferior a treze graus Gay Lussac.

No caso ora analisado, há também a possibilidade de se aplicar o princípio da proibição de insuficiência, tendo em vista o exame, pelo Judiciário, da necessidade de se reforçar o teor da única mensagem originariamente prevista para as bebidas alcoólicas pelo $\S 2^{\circ}$ do artigo $4^{\circ}$ da Lei $n^{\circ} 9.294 / 96$. A partir do exame de tal medida, verifica-se que o legislador não consagrou uma proteção suficiente. Mesmo que fosse afastada a regra do parágrafo único do artigo $1^{\circ}$ do mencionado diploma, o conteúdo da única advertência prevista seria insuficiente para uma proteção adequada. A advertência no sentido de se evitar o consumo excessivo de álcool não veicula informações necessárias a uma decisão adequada sobre consumir ou não o produto, como os malefícios que dele podem decorrer. A decisão judicial referida, portanto, a par de submeter todas as bebidas a restrições, no caso as relativas ao horário de exibição, de vedação de certos conteúdos e de veiculação de advertências, impôs a retificação do conteúdo destas últimas, no sentido de torná-las mais adequadas (verazes, completas, inequívocas e atualizadas). Também impôs uma alteração na forma de expressão das mensagens, o que também contribui para a referida adequação, já que muitas vezes os rótulos e embalagens de bebidas não dão o devido destaque às advertências. O mesmo se pode dizer da publicidade nos meios de comunicação de massa,

${ }^{68}$ SANTIAGO, José Maria Rodríguez de. La ponderación de bienes e interesses en el derecho administrativo, p. 135. 
que deverá se sujeitar a restrições de horário e de conteúdo e conter inserções adequadas das quais constem as mensagens referidas.

A circunstância de a veiculação de advertências ser uma medida de proteção menos restritiva que a proibição da publicidade ou a ilegalização do consumo permite afirmar que sua imposição consagra menor lesão ao âmbito protegido das liberdades de expressão e de iniciativa econômica. Ao se reconhecer a necessidade de veiculação de tal mensagem, não se está sobreavaliando os direitos à saúde e à informação. Já a possibilidade de uma auto-proteção suficiente por parte de consumidores e da generalidade das pessoas, especialmente crianças e adolescentes, é discutível, diante do potencial da publicidade para influenciar suas condutas. É de se lamentar, apenas, a restrição efetuada pelo STJ quanto à eficácia do acórdão do TRF da $4^{\mathrm{a}}$ Região, limitando-a ao seu âmbito de competência territorial, na forma do artigo 16 da Lei 7.347/1985. A matéria não parece comportar um tratamento diverso, quanto às regiões, por envolver bem de interesse de toda a sociedade (a tutela da saúde), merecendo um tratamento uniforme em todo o território nacional.

\section{CONCLUSÕES}

A proteção constitucionalmente outorgada ao consumidor, embora nem sempre estabeleça direitos subjetivos, permite identificar um dever de buscar um nível mínimo de suficiência das medidas estatais elaboradas para lhe dar concreção. No quadro de um Estado de Direito Constitucional, em que se impõe ao legislador a harmonização entre bens, direitos e valores conflitantes e a proteção adequada dos direitos fundamentais, o recurso ao princípio da proporcionalidade se mostra indispensável para determinar o caráter excessivamente gravoso ou manifestamente insuficiente das medidas previstas por atos do Poder Público. É possível, portanto, a intervenção do Poder Judiciário, determinando a adoção de uma medida de proteção, sempre que houver a redução a zero da discricionariedade do legislador ou do administrador, pela identificação de um único e determinado meio de atuação cabível no caso concreto, bem como pela demonstração de que as medidas de proteção ou não existem ou são manifestamente inadequadas ou insuficientes.

\section{BIBLIOGRAFIA}

ALEXY, Robert. Teoría de los Derechos Fundamentales, Madri: Centro de Estudios Políticos y Constitucionales, 2001.

ANDRADE. José Carlos Vieira de. Os Direitos Fundamentais na Constituição Portuguesa de 1976, Coimbra: Livraria Almedina, 2004.

Os Direitos dos Consumidores como Direitos Fundamentais na Constituição Portuguesa de 1976, in Boletim da Faculdade de Direito da Universidade de Coimbra, v. 58, p. 43-64, 2002.

. A Justiça Administrativa, Coimbra: Livraria Almedina, 2000.

BOBBIO, Norberto. A Era dos Direitos. Rio de Janeiro: Campus, 1992.

BONAVIDES, Paulo. Curso de Direito Constitucional. São Paulo: Malheiros, 2000.

DiReITOS FundaMentals E E JUSTIÇA - ANO 5, N 15, P. 79-105, ABR./Jun. 2011 
CANARIS, Claus-Wilhelm. Direitos Fundamentais e Direito Privado, tradução de Ingo Wolfgang Sarlet. Coimbra: Livraria Almedina, 2003.

CANOTILHO, J. J. Gomes. Direito Constitucional e Teoria da Constituição. Coimbra: Almedina, 2003.

Omissões Normativas e Deveres de Protecção. In: AAVV. Estudos em Homenagem a Cunha Rodrigues, v. 2. Coimbra: Coimbra Editora, 2001, p. 111-124, v. 2. DIDIER JR, Fredie e ZANETI JR., Hermes. Curso de Direito Processual Civil: processo coletivo, Salvador: Juspodium, 2007, v. 4.

DWORKIN, Ronald. Sovereign Virtue: the theory and practice of equality, Cambridge: Harvard University Press, 2000.

DENARI, Zelmo. Da Qualidade de Produtos e Serviços, da Prevenção e da Reparação de Danos. In: GRINOVER et al. Código de Defesa do Consumidor comentado pelos autores do anteprojeto, 7. ed. rev. e ampliada, Rio de Janeiro: Forense Universitária, 2001, p. 143-214.

FILOMENO, José Geraldo Brito. Dos Direitos do Consumidor. In: GRINOVER et al. Código de Defesa do Consumidor comentado pelos autores do anteprojeto, 7. ed. rev. e ampliada, Rio de Janeiro: Forense Universitária, 2001, p. 17-142.

GONÇALVES, Pedro. Advertências da Administração Pública. In: AAVV. Estudos em Homenagem ao Prof. Doutor Rogério Soares, Coimbra: Coimbra Editora, 2001, p. 723-796.

GOMES, Carla Amado. Os Novos Trabalhos do Estado: a administração pública e a defesa do consumidor. Disponível em:

<www.mundojuridico.adv.br/html/artigos/documentos/texto456.htm>.

Acesso em 11 maio 2005.

GUERRA FILHO, Willis Santiago. Processo Constitucional e Direitos Fundamentais. São Paulo: RCS Editora, 2007.

HÄBERLE, Peter. Le Libertà Fondamentali nello Stato Costituzionale. Roma: La Nuova Italia Scientifica, 1993.

HESSE, Konrad. Elementos de Direito Constitucional da República Federal da Alemanha. Porto Alegre: Sérgio Antonio Fabris Editor, 1998.

LARENZ, Karl. Metodologia da Ciência do Direito, Lisboa: Fundação Calouste Gulbenkian, 1989.

LÔBO, Paulo Luiz Netto. A Informação como Direito Fundamental do Consumidor. In Estudos de Direito do Consumidor, n. 3, Coimbra, Centro do Direito do Consumo, 23-45, 2001.

MACHADO, Jónatas. Liberdade de Expressão: dimensões constitucionais da esfera pública no sistema social. Coimbra: Coimbra Editora, 2002.

MOREIRA JR. Sebastião. A regulação da publicidade das bebidas alcoólicas. Disponível em: <www.senado.gov.br/web/conleg/textos_discussao/texto\%2020\%20-20sebastiao.pdf>. Acesso em 10 maio 2005.

NABAIS, José Casalta. Algumas Reflexões Críticas sobre os Direitos Fundamentais, in Revista de Direito Público da Economia, Ano 6, n. 22, abril/junho de 2008, Editora Fórum: Belo Horizonte, p. 61-95.

NOVAIS, Jorge Reis. As Restrições aos Direitos Fundamentais não Expressamente Autorizadas pela Constituição. Coimbra: Coimbra Editora, 2003. 
Os Direitos Fundamentais nas Relações Jurídicas entre Particulares, in Direitos Fundamentais - Trunfos contra a maioria. Coimbra: Coimbra Editora, 2006, p. 69-116. OTERO, Paulo. A Democracia Totalitária. Cascais: Principia, 2001.

PEREIRA, Jane Reis Gonçalves. Interpretação Constitucional e Direitos Fundamentais. Rio de Janeiro: Renovar, 2006.

PINTO, Paulo Mota. O Direito ao Livre Desenvolvimento da Personalidade. In: AAVV. Portugal-Brasil Ano 2000: tema direito, Coimbra: Coimbra Editora, 1999, p. 149-261.

SANTIAGO, José María Rodríguez de. La Ponderación de Bienes e Interesses en el Derecho Administrativo, Madri: Marcial Pons, 2000.

SARLET, Ingo Wolfgang. A Eficácia dos Direitos Fundamentais. Porto Alegre: Livraria do Advogado, 2003.

SCHWABE, Jürgen, org. Cincuenta Años de Jurisprudencia del Tribunal Constitucional Federal Alemán, Montevidéu; Bonn; Bogotá: Ediciones Jurídicas Gustavo Ibáñez/Konrad Adenauer Stiftung, 2003.

STEINMETZ, Wilson. A Vinculação dos Particulares a Direitos Fundamentais, São Paulo: Malheiros, 2004.

STRAUSS, David A. Persuasion, Autonomy, and Freedom of Expression. Columbia Law Review, v. 91, 1991, p. 334-371.

UBILLOS, Juan María Bilbao. Los Derechos Fundamentales en la Frontera entre lo Público y lo Privado: la noción de State action en la Jurisprudencia norteamericana. Madri: Mcgraw-Hill, 1997. 